\title{
Inspirational Women in Surgery: Dr. Nadine R. Caron, Canada
}

\author{
Janice L. Pasieka ${ }^{1}$ (B)
}

Accepted: 11 September 2021 / Published online: 4 October 2021

(C) Société Internationale de Chirurgie 2021

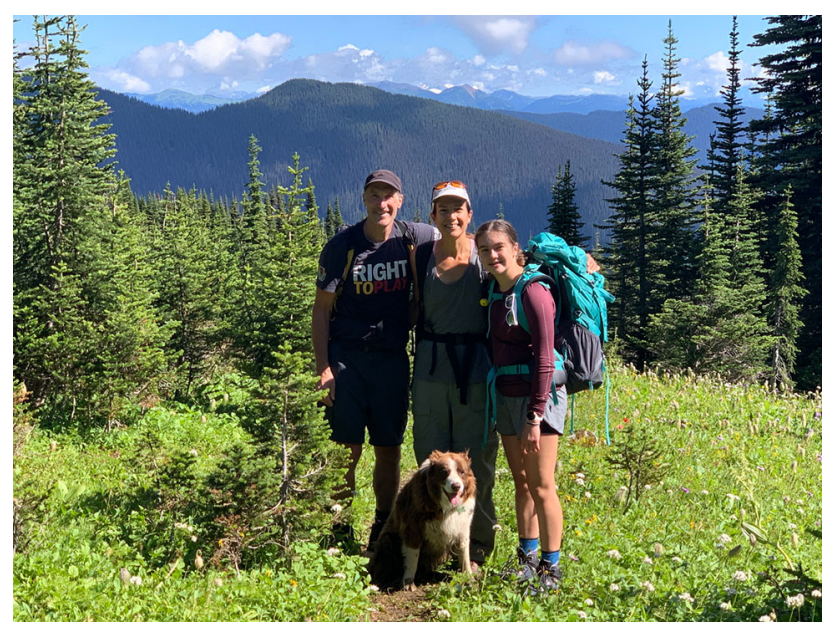

Nadine R. Caron is a Professor of Surgery at the University of British Columbia (UBC). She is based at the UBC Northern Medical Program in Prince George, British Columbia (BC). I first met Nadine when she was a thirdyear medical student doing a surgical elective in endocrine surgery at the University of Calgary. I like to think I was one of many influential mentors, and proudly followed her career. Yet, in this last decade, the roles of mentee and mentor have been reversed. For it is Nadine who has educated me on the disparities of health care delivery to our Indigenous population, broadened my awareness of the cultural diversity of our Indigenous Peoples, and like many

Janice L. Pasieka

janice.pasieka@ahs.ca

1 Department of Surgery, Section of General Surgery, University of Calgary, Cumming School of Medicine, Calgary, Canada others in Canada, is helping guide us in the dialog of reconciliation.

Dr. Caron was born and raised in Kamloops, BC, one of four children born to an Ojibwe mother (a school teacher) and an Italian immigrant father (a mason). She completed a degree in Kinesiology at Simon Fraser University while playing varsity basketball. Dr. Caron was the first female First Nations person to graduate from UBC Medical School. This was followed by a General Surgical residency at UBC, which included a Masters in Public Health from Harvard University, becoming the first female First Nation General Surgeon in Canada. Nadine went on to do an Endocrine Surgical Fellowship at the University of California, San Francisco, before settling in Prince George, BC with her husband Dr. Patrick Turner (an Emergency physician) and daughter Aliah (a budding biathlete). Nadine enjoys trail-running with her dogs, canoeing, cross country skiing and hiking with Pat, and watching Aliah compete in various sporting events. In 2009, she was appointed as an Associate Faculty member of the Bloomberg School of Public Health at Johns Hopkins University. Although she has numerous publications to her name, the most significant of her scholarly contributions is her role in the development and establishment as Co-Director of UBC's Centre for Excellence in Indigenous Health, which is now recognized as a pillar of the university's strategic plan. Most recently, Dr. Caron was appointed as the inaugural First Nations Health Authority Chair in Cancer and Wellness at UBC. Although Dr. Caron has many first achievements and awards bestowed upon her, which she is proud of, Nadine would be the first to ask the question 'why is it that I am the first,' and reflect upon what has stopped other females, First Nations Peoples, and other minorities from achieving these goals to date. 
As a surgeon, researcher, and a member of the Sagamok Anishnawbek First Nation, Dr. Caron has made a significant impact by advocating for the rights of marginalized and Indigenous peoples and is always looking for ongoing opportunities to address health disparities faced by Indigenous populations, communities, and individuals. As a friend, colleague, mentor, and role model to many, Dr. Caron continues to inspire and lead by example.

Publisher's Note Springer Nature remains neutral with regard to jurisdictional claims in published maps and institutional affiliations. 